\title{
Is receptor profiling useful for predicting pituitary therapy?
}

\author{
Monica Marazuela1, Ana M Ramos-Leví1, Patricia Borges de Souza² and \\ Maria Chiara Zatelli²
}

1Department of Endocrinology, Hospital Universitario La Princesa, Instituto de Investigación Princesa, Universidad Autónoma de Madrid, Madrid, Spain and ${ }^{2}$ Section of Endocrinology and Internal Medicine, Department of Medical Sciences, University of Ferrara, Ferrara, Italy

Correspondence should be addressed to M Marazuela or M C Zatelli Email

monica.marazuela@salud. madrid.org or ztlmch@unife.it

\begin{abstract}
Medical treatment of pituitary tumours may present important challenges in the presence of resistance to first-line therapy. In this setting, the availability of specific markers of responsiveness/resistance could be helpful to provide tailored patients' treatment. Pituitary receptor profiling has emerged as a potentially useful tool for predicting the response to specific pituitary-directed medical therapy, mainly somatostatin analogues and dopamine agonists. However, its utility is not always straightforward. In fact, agonist-receptor coupling to the consequent biological response is complex and sometimes jeopardizes the understanding of the molecular basis of pharmacological resistance. Defective expression of pituitary receptors, genetic alterations, truncated variants, impaired signal transduction or involvement of other proteins, such as cytoskeleton proteins or the aryl hydrocarbon receptorinteracting protein amongst others, have been linked to differential tumour phenotype or treatment responsiveness with conflicting results, keeping the debate on the utility of pituitary receptor profiling open. Why does this occur? How can we overcome the difficulties? Is there a true role for pituitary receptor profiling in the near future? All authors of this debate article agree on the need of prospective studies using standardized methods in order to assess the efficacy of receptor profiling as a reliable clinical predictive factor.
\end{abstract}

\section{Introduction}

Functioning and non-functioning pituitary tumours (PTs) entail a challenging set of diseases with intrinsic diagnostic and treatment difficulties, frequently associated with increased morbidity and mortality. Tumour resection is the first-line treatment for many PTs; however, surgery is not always feasible or curative and adjuvant therapy is attempted (1). Approximately $10-30 \%$ of patients will not respond to the currently recommended medical therapy in terms of PT bulk reduction and/or hormonal secretion inhibition. In this setting, biochemical, radiological, histological, immunological, genetic or molecular markers would be truly helpful for the individualization of patients' treatment and would enable a relevant shift in the therapeutic decision-making process towards an
European Journal of Endocrinology

(2018) 179, D15-D25 individualized and personalized medicine. In addition, this strategy would allow to establish realistic prognostic and predictive values of specific biomarkers, for a more efficient and cost-effective approach, especially in the long term.

In this setting, in the era of personalized medicine, pituitary receptor profiling has emerged as a potentially useful tool for predicting the response to specific pituitarydirected treatments, mainly somatostatin analogues (SSAs) and dopamine agonists (DAs). This approach could allow to optimize patients' management and, consequently, reduce the burden of health care costs, as well as of side effects. However, its utility is not always straightforward. We here review and discuss the pros

Published by Bioscientifica Ltd. 
and cons of somatostatin (SSTR) and dopamine receptor (DR) profiling in PT and suggest future investigational perspectives.

\section{Somatostatin and DRs in PTs}

Pathological findings in pituitary cells have proved the existence of several cell membrane receptors, including SSTR and DR, which modulate pituitary cell proliferation and hormonal secretion. In this regard, five SSTR subtypes have been described (SSTR1-5), which are encoded by genes localized on different chromosomes, with two SSTR2 isoforms, SSTR2A and SSTR2B, generated via alternative splicing. Furthermore, two non-canonical truncated SSTR5-splice variants have been revealed and termed sst5TMD4 and sst5TMD5, due to the fact that they exhibit four and five transmembrane domains, respectively (2). The five canonical SSTRs share 40-60\% homology (3), but the elicited effects are different according to the SSTR profile on the cell surface. SSTR can form heterodimers with dopamine, opioid, epidermal growth factor receptors or other SSTR subtypes $(4,5,6,7)$, which generate receptor oligomers with unique pharmacological profiles. Similar to other G-protein-coupled receptors, SSTRs regulate their responsiveness to continued agonist exposure by showing different degrees of receptor internalization and degradation (8), as also demonstrated in other neuroendocrine neoplasms (9). In addition, two main subtypes of DR, DR1 and DR2, are expressed in pituitary tissues (10).

PTs retain SSTR and DR expression, whose activation elicits different effects, depending on the specific pituitary cell type (11). sst5TMD4, on the other hand, has been found to be rarely expressed in normal tissues, whilst it is overexpressed in PT, breast and thyroid cancer (12, 13, 14). Thus, presumably, targeted pharmacological treatments may be developed, allowing control of tumour cell metabolism. Long-acting SSA, octreotide (OCT) and lanreotide (LAN), have a high binding affinity for SSTR2 and, to a lesser extent, to SSTR5 and SSTR3 $(3,15)$, whilst the new-generation drug, pasireotide, is a multi-receptortargeted SSTR ligand, which binds with high affinity both SSTR2 and SSTR5 (16). In addition, pasireotide induces rapid SSTR2 recycling to the plasma membrane after endocytosis, reducing the desensitization effect (17). Preclinical and clinical studies demonstrated the efficacy of long-acting SSA in the treatment of PT, particularly GH (18) and TSH-secreting tumours (19). Moreover, international multi-centre studies demonstrated the efficacy of pasireotide in the medical management of Cushing's disease $(20,21)$ and GH-secreting PTs (22). Cabergoline, on its side, is an ergot-derived DA with high affinity for DR2 and lower affinity for DR1, $\alpha 1$ - and $\alpha 2$ adrenergic, and 5-HT1- and 5-HT2-serotonin receptors (23, 24). Cabergoline has proved to be effective for the medical management of prolactinomas, as it allows control of clinical symptoms, prolactin (PRL) level reduction and tumour volume shrinkage. In addition, this drug could be useful also for selected ACTH- and GH-secreting PT and non-functioning PT $(25,26,27)$.

However, the tandem mediator - receptor - response is not always as simple and straightforward as we would desire from a clinical point of view. In fact, there is sometimes a dissociation between the presence of a receptor and the observed response. For instance, some tumours may express the receptor but do not respond to specific therapy, whilst some patients whose tumours do not express a particular receptor may adequately respond to targeted treatment. To complicate things even more, there have been differences in the techniques used for analysing SSTRs across the literature; some studies detected mRNA with quantitative polymerase chain reaction (qPCR) or reverse-transcription (RT)-qPCR, others quantified the amount of protein using immunohistochemistry (IHC) or Western blot techniques, and some studies were performed in vivo using scintigraphy.

\section{FOR: The case for pituitary receptor profiling}

\section{The somatostatin receptor family in the aid of pituitary tumour treatment}

SSTRs are normally expressed in the adult pituitary. SSTR5 is the predominant subtype in normal human pituitary, followed by SSTR2, SSTR1, SSTR3 and SSTR4. Canonical SSTRs are heterogeneously expressed in PT, whereas the sst5TMD4 splice variant has been found to be overexpressed in PT, breast and thyroid cancer $(12,13,14)$. Several studies focused on SSTR characterization with the use of different techniques, from qPCR $(11,28,29,30)$ to $\operatorname{IHC}(31,32,33)$ and in vivo scintigraphy $(31,34,35)$. Some reports have characterized SSTR3 as the predominant SSTR expressed in certain acromegaly cases resistant to first-generation SSA, which could explain the lack of response (36). Nonetheless, SSTR2 has proved to be the most frequently expressed SSTR reported in acromegaly studies (29). In these settings, SSTR2 expression has been the focus of 
many studies attempting to identify a pattern to predict SSA response. Besides SSTR heterogeneous expression, low SSTR levels or reduced receptor density may explain the proportion of patients partially or completely resistant to SSA and, therefore, pituitary receptor profiling could help predict the response to specific treatments.

\section{SSTR2 and SSTR5: role in response to SSA}

First-generation SSA, OCT and LAN, are considered the first-line medical treatment in acromegaly when surgery fails to control the disease. However, $20-25 \%$ of patients present resistance to OCT and LAN treatment. Resistant patients are defined as those who show a reduction $<50 \%$ in GH and IGF1 levels, a decrease of $<20 \%$ in tumour mass or an increase in size during treatment (37). In general, 9-12 months are necessary to assess treatment outcome. Apart from an inefficient high-cost therapy, poor responsiveness leads to patient exposure to the deleterious effects of excessive GH and IGF1 levels for several months. Studies concerning PT and the possibility to predict tumour response to first-generation SSA started in the late 90s. Using different techniques, such as ${ }^{111}$ In-pentetreotide scintigraphy, MRI, Northern blot, PCR, researchers have found a correlation between SSTR positivity and hormonal response to OCT and/or LAN $(35,38,39,40)$. For instance, the ability to visualize GH-secreting PT with ${ }^{111}$ In-pentetreotide scintigraphy positively correlated with the ability to reduce GH secretion by OCT (38). A clear correlation has also been found between SSTR2 expression levels, assessed by Northern blot, and in vivo and in vitro sensitivity to OCT (39). In the following years, several studies investigated SSTR2 expression as a biomarker to predict PT response to first-generation SSA. Indeed, several studies have shown that SSTR2 strongly correlates with hormonal suppression and, hence, tumour responsiveness to SSA therapy. With the advent of qPCR, SSTR expression has become accessible and has been used by the majority of studies attempting to define a correlation between SSTR expression and medical outcome. Specifically, OCT efficacy in decreasing hormonal secretion has been positively correlated with SSTR2 mRNA levels, mainly in GH-secreting tumours $(11,29,41)$. The fact that SSTR2 could help predict PT response to first-generation SSA has also been described in IHC reports. The use of IHC for SSTR2A detection in specimens obtained by surgery has been recommended since the results were useful in identifying patients with acromegaly who could benefit from SSA treatment $(32,33,42,43)$.
The list of evidences regarding the usefulness of SSTR profiling is long and still growing. In a series of 22 somatotropinomas, SSTR1-5 mRNA absolute copy numbers were assessed by RT-PCR and response to OCT long-acting repeatable (LAR) was evaluated by measuring hormone levels (GH and IGF1) and tumour volume. In this study, SSTR5 was the predominantly expressed SSTR, followed by SSTR2, SSTR3, SSTR1 and SSTR4. A positive correlation was found between SSTR2 expression levels and decreased hormone secretion at 3 months, as well as tumour volume reduction after 6 months of treatment. On the other hand, SSTR5 negatively correlated with the decrease in hormone levels. Furthermore, a higher SSTR2/ SSTR5 ratio was observed in controlled patients with OCT LAR when compared with those uncontrolled (29). Even though final SSTR presence on cell membrane was not evaluated in this study, the reported results support the evidence that mRNA levels may still be useful in predicting SSA responsiveness in GH-secreting tumours. In another study considering 88 somatotropinomas, Wildemberg et al. found that a low SSTR2A expression is a strong negative predictive factor for biochemical response to first-generation SSA. In this study, SSTR expression was assessed by IHC, and there was a positive correlation between SSTR2 mRNA and protein levels (44). Since IHC is routinely used to assess PT, IHC SSTR2 analysis could help predict responsiveness to first-generation SSA and improve patient management. Indeed, another study by Gatto et al. demonstrated that the results of IHC, performed with a SSTR2A rabbit monoclonal antibody, overlap those of RT-PCR. In this study, the authors found a strong correlation between SSTR2A immunostaining and IGF1 normalization after SSA treatment (45). Interestingly, densely granulated tumours, which are better responders to SSA, have higher SSTR2A expression levels as compared to sparsely granulated tumours (46). In addition, sst5TMD4 has been reported to have a dominant negative effect on SSTR2 signalling and could explain the resistance to first-generation SSA in patients with PT displaying high SSTR2 expression (47). In a comparison study between OCT and pasireotide, somatotropinomas that exhibited low SSTR2 and lower SSTR2/SSTR5 ratio at mRNA level were better responders to this novel SSTR ligand (48). A similar result has been described in an IHC study, where SSTR5 was found to be a predictor of response to pasireotide in patients whose disease was not controlled by treatment with first-generation SSA. None of the patients lacking SSTR5 was responsive to the treatment, whereas cases with higher SSTR5 expression showed a greater reduction in IGF1 levels. In addition, 


\section{SSTR expression correlates with response to SSA \\ SSTR expression studied with qPCR, rtPCR, Western Blot, IMHQ, scintigraphy \\ Pituitary adenomas preserve nomal SSTR expression and molecular pathways

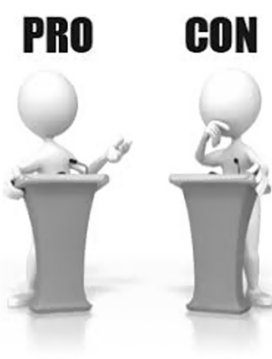 \\ Variable SSTR expression \\ Heterogeneity in the techniques used for analyzing SSTR \\ Potential mechanisms of SSA resistance: truncated variants, AIP, ZAC, e-cadherin, filamin A...}

First and second generation SSA useful for biochemical and tumor volume control

Results cannot be extrapolated if drugs and time of administration are different

Outcome evaluation: GH, IGF-I, tumor volume

Outcome must be equivalent to be able to compare

DR expression correlates with response to dopamine agonists

Heterogeneity and bias of published studies

\section{Figure 1}

Summary of the main concerns regarding the advantages and disadvantages of pituitary receptor profiling for the management of pituitary tumours. DR, dopamine receptors; SSA, somatostatin analogues; SSTR, somatostatin receptors.

a positive correlation between SSTR2A immunostaining, assessed with the same IHC approach, and first-generation SSA response was confirmed. As expected, only cases with membranous receptor expression were responsive to the treatment, confirming that SSTR presence on cell membrane is a prerequisite for the responsiveness to these drugs (49). High SSTR5 and low SSTR2 expression has also been reported in ACTH-secreting tumours (50), where low SSTR2 levels are probably due to high circulating cortisol levels, that are not found in acromegaly. Indeed, the imbalance in SSTR2/SSTR5 expression may deeply influence corticotroph tumour responsiveness to Pasireotide, indicating that disease activity, mainly depending on circulating cortisol levels, may profoundly impair SSA efficacy in Cushing's disease (51). On the contrary, there is no evidence that $\mathrm{GH}$ circulating levels may affect SSTR expression, thereby influencing the responsiveness of GH-secreting PTs to SSTR ligands. Cushing's disease usually benefits from pasireotide therapy and, in fact, this drug has been approved for the medical treatment of corticotropinomas $(20,21,52,53,54)$.

The results of the studies reported here indicate that in GH-secreting PT high SSTR2 levels and SSTR2/SSTR5 ratio associate with responsiveness to first-generation SSA, whilst low SSTR2 levels and high SSTR/SSTR5 ratio favours pasireotide efficacy. In ACTH-secreting PT, on the other hand, low SSTR2 levels may account for the scant efficacy of first-generation SSA, supporting the use of pasireotide, which may also act by binding SSTR5.

\section{Other SSTR involved?}

SSTR family comprises receptors different from SSTR2 and SSTR5, which could play an important role in patients poorly responsive to SSA. An in vitro study has demonstrated that activation of SSTR1 by a SSTR1-selective ligand decreased GH and PRL secretion, as well as reduced cell viability, in tumour cells derived from acromegalic patients. In this study, SSTR1 mRNA levels correlated with the extent of hormone secretion inhibition induced by the SSTR1-selective agonist (55). In another in vitro study, the same SSTR1-selective agonist was able to inhibit chromogranin A secretion and reduce cell viability in non-functioning PT (NFPT) (56), confirming a possible role for this SSTR in SSA response. Another example is SSTR3, for which an important role has been proposed in mediating tumour shrinkage in somatotropinomas (36), NFPT (11) and gonadotropinomas (57). 
Overall, these findings regarding SSTR family support the proposal that receptor pituitary profiling could be a useful tool for PT patient stratification. A standardized evaluation of SSTR expression, which is feasible and relatively low cost, could represent a valid option that could lead to personalized medicine in PT, allowing to optimize patient management and, consequently, reduce the burden of health care costs, as well as of side effects.

\section{Is the DR pathway useful?}

Systematic and meta-analysis studies regarding DR expression profile in the different tumour cell populations are scarce, though it has been demonstrated that DR2 is present in nearly $90 \%$ of all PT including PRL-, GH-, ACTH-secreting PT and NFPT $(58,59,60)$. In PRL-secreting tumours, DA such as cabergoline and bromocriptine, are the gold-standard treatment for both micro- and macroadenomas according to the Endocrine Society Clinical Practice Guidelines $(61,62)$. A small number of patients (5-10\%) is defined as non-responder due to resistance to DA (63). It has been reported that one strategy to improve treatment in these resistant patients is to gradually increase DA dose, although adverse effects should be accurately evaluated. In a prospective study using high cabergoline doses, normalization of PRL levels was achieved in $96.2 \%$ of patients after increasing the dose up to $12 \mathrm{mg}$ per week (64). Possible predictors of resistance in prolactinomas have been suggested, such as male gender and tumour diameter $>1 \mathrm{~cm}(65,66)$. Men usually harbour macroprolactinomas with symptoms of sellar mass effect at presentation whilst microprolactinomas are usually diagnosed in women aged 20-50 years presenting symptoms of hypogonadism. Some authors have proposed that these differences in presentation could be in part explained by the fact that hypogonadism in males is usually neglected and medical attention is sought later, possibly allowing the development of a DA-resistant phenotype (i.e. due to decreased DR2 expression) (67, 68). On the contrary, other authors provide evidence for the lack of a gender prevalence in D-resistant prolactinomas (66).

Previous reports have found that prolactinomas that are bromocriptine resistant have a four-fold decrease in DR2 expression when compared with responsive prolactinomas (69). In addition, a polymorphism causing a cytosine-to-thymine transition at position 957 in DR2 gene has been associated with faster DR2 mRNA decay, which could explain reduced receptor expression (70) and, consequently, DA resistance. Fusco et al. reported a comparison study between the efficacy of SSA, cabergoline and a chimeric SSA-DA compound (BIM23A760) in suppressing PRL secretion in DA-resistant prolactinomas. The results of this study confirmed that compounds targeting DR2 remain the best option in the treatment of prolactinomas. Moreover, DR2 mRNA levels in DA-resistant tumours were significantly lower as compared to those found in DA-sensitive prolactinomas, indicating a possible correlation between DR status and DA response (71). Failure of medical treatment usually leads to transsphenoidal surgery, the second-line treatment, in particularly resistant subjects. Pituitary receptor profiling could help predict receptor target status, aiding the selection of the best therapeutic approach.

The results of the studies reported here indicate that DR2 status could influence PRL-secreting tumour responsiveness to DA. DR decreased expression levels may account for the limited DA efficacy in resistant patients and other medical therapies, such as chimeric SSA-DA compounds, should be considered.

\section{AGAINST: the case against pituitary receptor profiling}

\section{The somatostatin receptor pathway: a cumbersome route}

The occasional lack of correlation observed between the use of SSA and its associated pathological and clinical responses may be explained by several reasons. First, there is a variable expression of SSTR in different tumours. Second, the expression and methods for detection of SSTRs have been variable across studies. In addition, the treatment used in different studies has not always been the same; some studies were performed using first-generation SSA, whilst others used the newly available pasireotide. Another point of heterogeneity is whether patients had been pretreated or not with SSA. In addition, it is also important to know which outcome was measured, that is, if they were evaluating the decrease in GH and IGF1 levels and/or if they were studying a possible decrease in tumour volume. All these heterogeneities encumber trustworthy and comparable conclusions.

\section{Variability in the expression of SSTRs}

PTs may be heterogeneous regarding the expression of specific receptors, both from a qualitative and quantitative point of view. For instance, some tumours express low levels of SSTR2, but high levels of SSTR5 $(46,72,73)$; other 
tumours express low levels of both SSTR2 and SSTR5. The former situation could lead to an incomplete resistance to first-generation SSA that mainly exert their action by binding SSTR2, and the latter could still be sufficient for an adequate response to SSA because of an additive effect mediated by a functional interaction between SSTR2 and SSTR5.

\section{Heterogeneity in the techniques used for analysing SSTRs}

Concerning studies in the setting of acromegaly, there have been differences in the techniques used for analysing SSTRs; some studies detected mRNA with qPCR or RT-qPCR, others quantified the amount of protein using IHC or Western blot techniques and some studies were performed in vivo using scintigraphy. It would be truly interesting if this latter technique could predict SSA response, but large studies have failed to prove its relevance $(34,38)$.

Although many studies have reported a correlation between SSTR measurement and response to SSA, this has not been always the case. In this regard, Corbetta et al. (74) did not find any significant correlation between SSTR, measured by mRNA, and in vivo responsiveness in 19 somatotropinomas. Park et al. (28) could not prove a correlation between SSTR2 and SSTR5 mRNA expression and GH values in 16 somatotropinomas. Gonzalez et al. (75) reported that neither SSTR2 nor SSTR5 expression correlated with baseline or post OCT GH or IGF1 levels or tumour volume by qPCR or IHC in 60 somatotropinomas. Takei et al. (42) studied 22 somatotropinomas using IHC and found that SSTR2 protein levels correlated positively with GH suppression, but, in contrast, SSTR5 did not show any correlation with $\mathrm{GH}$ levels. Ibañez-Costa et al. (76) evaluated IHC and function in 32 somatotropinomas and described that OCT and LAN significantly and similarly decreased GH secretion and cell viability, without evident correlation between the response and SSTR expression pattern. Moreover, analysis of the differences reported in studies that used IHC denote a wide range of heterogeneity, mainly because of the employed antibody (monoclonal vs polyclonal antibodies), the studied cell fraction (cell membrane fraction or both cytoplasm plus cell membrane fraction) and the scoring system (intensity, amount or the Remmele IRS score, etc.) $(42,44,45,77,78$, 79). A universal scoring system has been proposed (45) to try to overcome some of these heterogeneities when comparing different SSA actions.

\section{Preoperative treatment and specific SSA used}

Whilst in some studies patients were treated with firstgeneration SSA (OCT and LAN), some patients received therapy with the newly available pasireotide. As first generation and the new SSTR agonist interact with different SSTRs, results are not always overlapping.

Regarding pre-surgical therapy with SSA, SSTR2 expression is probably consequently reduced, thus encumbering a reliable interpretation on the relationship between SSTR expression and GH-IGF1 reduction, which becomes even more difficult to interpret. In the study by Casar-Borota et al. (77) of 65 somatotropinomas treated with OCT, SSTR2 expression levels were reduced in the pretreated group and positively correlated with $\mathrm{GH}$ and IGF1 reduction. However, no correlation was found between tumour volume reduction and SSTRs. Fougner et al. (80), on their part, evaluated 71 somatotropinomas also treated with OCT and found that SSTR2 was positively correlated with $\mathrm{GH}$ reduction after an acute OCT test in patients who did not receive SSA pre-treatment but, in contrast, they did not find any correlation in patient who were pretreated with OCT. Moreover, SSTR2 protein level assessed by Western blot did not correlate with the response to OCT.

\section{Outcome evaluation: GHIIGF1 reduction and/or tumour volume reduction}

Many studies have evaluated GH and IGF1 response to SSA. However, there are few studies that have evaluated SSA efficacy regarding tumour volume reduction. In this regard, although there are some studies that found a relationship between tumour volume reduction and SSTR2 expression (29), no relationship was found in others.

All the above-mentioned findings regarding SSTR expression jeopardize trustworthy interpretation of studies and elaboration of definitive conclusions. In fact, measurement of SSTR expression may be promising, but it is difficult, and its utility for the prediction of clinical outcomes is not so straightforward. The presence of SSTR does not unequivocally ensure an adequate response to SSA.

\section{Impaired signal transduction}

Several mechanisms are involved in the impairment of signal transduction mediated by SSTRs, which concern the SHP1-PI3k-Akt, SHP2-MAPK, PLC, PKA A, RKIP, gsp, AIP-ZAC1, E-cadherin, B-arrestin and filamin A pathways. These pathways may be defective, so the corresponding migration, angiogenesis, secretion, proliferation and apoptosis functions may be impaired, leading to potential variability in the efficacy of SSA $(45,81,82)$. 
Specifically, the presence of the SSTR5-truncated isoforms has been correlated with a reduced response to SSA in GH-secreting tumours; for instance, sst5TMD4 was reported as particularly abundant in OCT-resistant somatotropinomas, suggesting its potential role in the attenuated response to SSA observed in some PT (83). The aryl hydrocarbon receptor-interacting protein (AIP) is another issue of interest, since several studies have observed how its low expression may be also associated with a worse response to SSA $(81,84)$. B-arrestins, on their part, seem to affect the desensitization-internalization process of G-protein-coupled receptors, including SSTR, and they have been involved, for instance, in the recycling of SSTRs in GH- and PRL-secreting PT. Thus, low expression of B-arrestin in GH- and PRL-secreting tumours, in comparison to NFPT, has been associated with reduced recycling rate of SSTR2, a higher amount of biologically active receptor exposed on the cell membrane, and a better response to SSA in terms of GH suppression, both in vitro and in vivo (85). In addition, low levels of filamin A, which is required for both DR2 and SSTR2 intracellular signalling, have been associated to a worse response to SSA (85). In addition, the expression of E-cadherin in somatotroph PT was related to tumour size, invasiveness and SSA response (86).

Therefore, other variables different from SSTR expression levels may influence SSA responsiveness and should be taken into account when trying to explore predictive factors of PT therapeutic response.

\section{The DR pathway: another challenge to overcome}

It has been extensively demonstrated, with various techniques, that DRs are expressed in the large majority of PT, including GH, PRL, ACTH secreting and NFPT. In this setting, DA seems a relevant targeted treatment, mediated through their interaction with DR. We know less about DR expression in prolactinomas, since only around 10\% of patients with these tumours finally undergo surgery, in most cases due to DA failure to normalize hormone secretion and reduce tumour volume. However, findings up to date do not seem to aid unequivocally in the prediction of clinical outcomes in prolactinomas. In fact, although the majority of reports show an apparent association between DR2 expression and DA response, some studies have not corroborated this correlation. A possible bias that we must consider is precisely the fact that only those prolactinomas that behave more aggressively and are resistant to medical treatment are the ones that have provided molecular information. In this regard, resistance to DA has been linked to a reduction or loss of DR2, to variations in the ratio between the short and long isoforms, which are thought to activate distinct intracellular pathways and mediate differential effects following ligand activation or to post-receptor mechanisms. Caccavelli et al. (69) indeed found an association between response to bromocriptine and DR2 expression in prolactinomas and observed that resistant tumours showed a reduced binding to DR2. In the same line, Fusco et al. (71) described an apparent association between lower DR2 levels and reduced response to DA, with no relationship with SSTR status. However, Shimazu et al. (87) did not find an association between DR2 status and resistance to cabergoline in 12 surgically treated resistant prolactinomas that were studied at mRNA and IHC level. They described that resistance to cabergoline was correlated with a reduction in DR2 long isoform levels.

If we consider the setting of acromegaly, Ferone et al. (43) found that SSTR2 and DR2 were positively correlated with in vitro and in vivo percent GH suppression by OCT in 24 somatotropinomas. In contrast, Neto et al . (58) who evaluated 39 somatotropinomas and observed a predominant expression of DR2, could not prove a significant difference in the expression of this receptor between controlled and uncontrolled acromegalic patients.

In light of these reports, where there is not a complete agreement regarding the relationship between receptor expression and DA response, we cannot assure that knowledge of pituitary DR status will allow straightforward predictions on medical outcome. Moreover, aberration of subsequent molecular pathways involved in the DA-DR interaction, including the ones related to NGF receptors, filamin A and Goi2, may contribute to heterogeneities in the observed response $(63,88)$. DR status may probably help to predict response to DA, but evidence is still not sufficient to establish fully accurate conclusions.

\section{Conclusions}

Based on the available information up to date, we cannot conclude in favour or against profiling pituitary receptors as a useful tool to predict PT treatment response. Indeed, the evidence that SSTR profiling predicts response to SSA treatment in GH-secreting PT is supported by some studies but not by others. Many other variables should be taken into account, including variations in other proteins, such as AIP, ZAC, B-arrestin, filamin or E-cadherin, which may 
lead to dissociated responses. Moreover, heterogeneity in measuring techniques may disguise the true relevance of SSA/DA receptor profiling and differences across studies in the treatments used or the criteria considered may bias the resulting conclusions (Fig. 1).

There is a lack of systematic reviews and metaanalyses regarding receptor subtyping and definition of medical outcome. In addition, most studies lack an analysis of sensitivity and specificity. We need prospective studies of patients after surgery using standardized methods. It would be very important to assess the quality of antibodies in IHC studies, as well as the development of a uniform and standardized scoring system, to facilitate routine evaluation of SSTR and DR expression in PT and allow reliable clinical predictions.

\section{Declaration of interest}

The authors declare that there is no conflict of interest that could be perceived as prejudicing the impartiality of this article.

\section{Funding}

This research did not receive any specific grant from any funding agency in the public, commercial or not-for-profit sector.

\section{References}

1 Dallapiazza RF \& Jane JA. Outcomes of endoscopic transsphenoidal pituitary surgery. Endocrinology and Metabolism Clinics of North America 201544 105-115. (https://doi.org/10.1016/j.ecl.2014.10.010)

2 Durán-Prado M, Gahete MD, Martínez-Fuentes AJ, Luque RM, Quintero A, Webb SM, Benito-López P, Leal A, Schulz S, GraciaNavarro F et al. Identification and characterization of two novel truncated but functional isoforms of the somatostatin receptor subtype 5 differentially present in pituitary tumors. Journal of Clinical Endocrinology and Metabolism 200994 2634-2643. (https://doi. org/10.1210/jc.2008-2564)

3 Patel YC. Somatostatin and its receptor family. Frontiers in Neuroendocrinology 199920 157-198. (https://doi.org/10.1006/ frne.1999.0183)

4 Rocheville M, Lange DC, Kumar U, Sasi R, Patel RC \& Patel YC. Subtypes of the somatostatin receptor assemble as functional homoand heterodimers. Journal of Biological Chemistry 2000275 7862-7869. (https://doi.org/10.1074/jbc.275.11.7862)

5 Pfeiffer M, Koch T, Schröder H, Klutzny M, Kirscht S, Kreienkamp HJ, Höllt V \& Schulz S. Homo- and heterodimerization of somatostatin receptor subtypes. Inactivation of sst 3 receptor function by heterodimerization with sst2A. Journal of Biological Chemistry 2001 276 14027-14036. (https://doi.org/10.1074/jbc.M006084200)

6 Pfeiffer M, Koch T, Schröder H, Laugsch M, Höllt V \& Schulz S. Heterodimerization of somatostatin and opioid receptors crossmodulates phosphorylation, internalization, and desensitization. Journal of Biological Chemistry 2002277 19762-19772. (https://doi. org/10.1074/jbc.M110373200)

7 Watt HL, Kharmate GD \& Kumar U. Somatostatin receptors 1 and 5 heterodimerize with epidermal growth factor receptor: agonistdependent modulation of the downstream MAPK signalling pathway in breast cancer cells. Cellular Signalling 200921 428-439. (https:// doi.org/10.1016/j.cellsig.2008.11.012)
8 Hofland LJ \& Lamberts SWJ. The pathophysiological consequences of somatostatin receptor internalization and resistance. Endocrine Reviews 200324 28-47. (https://doi.org/10.1210/er.2000-0001)

9 Zatelli MC, Maffei P, Piccin D, Martini C, Rea F, Rubello D, Margutti A, Culler MD, Sicolo N \& degli Uberti EC. Somatostatin analogs in vitro effects in a Growth Hormone-releasing hormone-secreting bronchial carcinoid. Journal of Clinical Endocrinology and Metabolism 200590 2104-2109. (https://doi.org/10.1210/jc.2004-2156)

10 Stefaneanu L, Kovacs K, Horvath E, Buchfelder M, Fahlbusch R \& Lancranjan L. Dopamine D2 receptor gene expression in human adenohypophysial adenomas. Endocrine 200114 329-336. (https:// doi.org/10.1385/ENDO:14:3:329)

11 Taboada GF, Luque RM, Bastos W, Guimaraes RFC, Marcondes JB, Chimelli LMC, Fontes R, Mata PJP, Filho PN, Carvalho DP et al. Quantitative analysis of somatostatin receptor subtype (SSTR1-5) gene expression levels in somatotropinomas and non-functioning pituitary adenomas. European Journal of Endocrinology $2007 \mathbf{1 5 6}$ 65-74. (https://doi.org/10.1530/eje.1.02313)

12 Luque RM, Ibáñez-Costa A, Neto LV, Taboada GF, HormaecheaAgulla D, Kasuki L, Venegas-Moreno E, Moreno-Carazo A, Gálvez MÁ, Soto-Moreno A et al. Truncated somatostatin receptor variant sst5TMD4 confers aggressive features (proliferation, invasion and reduced octreotide response) to somatotropinomas. Cancer Letters 2015359 299-306. (https://doi.org/10.1016/j.canlet.2015.01.037)

13 Puig-Domingo M, Luque RM, Reverter JL, López-Sánchez LM, Gahete MD, Culler MD, Díaz-Soto G, Lomeña F, Squarcia M, Mate JL et al. The truncated isoform of somatostatin receptor5 (sst5TMD4) is associated with poorly differentiated thyroid cancer. PLOS ONE 2014 9 e85527. (https://doi.org/10.1371/journal.pone.0085527)

14 Molè D, Gentilin E, Ibañez-Costa A, Gagliano T, Gahete MD, Tagliati F, Rossi R, Pelizzo MR, Pansini G, Luque RM et al. The expression of the truncated isoform of somatostatin receptor subtype 5 associates with aggressiveness in medullary thyroid carcinoma cells. Endocrine 201550 442-452. (https://doi.org/10.1007/s12020015-0594-x)

15 Ben-Shlomo A \& Melmed S. Pituitary somatostatin receptor signaling. Trends in Endocrinology and Metabolism 201021 123-133. (https://doi.org/10.1016/j.tem.2009.12.003)

16 Schmid HA. Pasireotide (SOM230): development, mechanism of action and potential applications. Molecular and Cellular Endocrinology 2008286 69-74. (https://doi.org/10.1016/j.mce.2007.09.006)

17 Lesche S, Lehmann D, Nagel F, Schmid HA \& Schulz S. Differential effects of octreotide and pasireotide on somatostatin receptor internalization and trafficking in vitro. Journal of Clinical Endocrinology and Metabolism 200994 654-661. (https://doi. org/10.1210/jc.2008-1919)

18 Colao A, Auriemma RS, Rebora A, Galdiero M, Resmini E, Minuto F, Lombardi G, Pivonello R \& Ferone D. Significant tumour shrinkage after 12 months of lanreotide Autogel-120 mg treatment given firstline in acromegaly. Clinical Endocrinology 200971 237-245. (https:// doi.org/10.1111/j.1365-2265.2008.03503.x)

19 Fukuhara N, Horiguchi K, Nishioka H, Suzuki H, Takeshita A, Takeuchi Y, Inoshita N \& Yamada S. Short-term preoperative octreotide treatment for TSH-secreting pituitary adenoma. Endocrine Journal 201562 21-27. (https://doi.org/10.1507/endocrj.EJ14-0118)

20 Schopohl J, Gu F, Rubens R, Van Gaal L, Bertherat J, LiguerosSaylan M, Trovato A, Hughes G, Salgado LR, Boscaro M et al. Pasireotide can induce sustained decreases in urinary cortisol and provide clinical benefit in patients with Cushing's disease: results from an open-ended, open-label extension trial. Pituitary 201518 604-612. (https://doi.org/10.1007/s11102-014-0618-1)

21 Findling JW, Fleseriu M, Newell-Price J, Petersenn S, Pivonello R, Kandra A, Pedroncelli AM \& Biller BMK. Late-night salivary cortisol may be valuable for assessing treatment response in patients with Cushing's disease: 12-month, Phase III pasireotide study. Endocrine 201654 516-523. (https://doi.org/10.1007/s12020-016-0978-6) 
22 Gadelha MR, Bronstein MD, Brue T, Coculescu M, Fleseriu M, Guitelman M, Pronin V, Raverot G, Shimon I, Lievre KK et al. Pasireotide versus continued treatment with octreotide or lanreotide in patients with inadequately controlled acromegaly (PAOLA): a randomised, phase 3 trial. Lancet Diabetes and Endocrinology 20142 875-884. (https://doi.org/10.1016/S2213-8587(14)70169-X)

23 An JJ, Cho SR, Jeong DW, Park KW, Ahn YS \& Baik JH. Antiproliferative effects and cell death mediated by two isoforms of dopamine D2 receptors in pituitary tumor cells. Molecular and Cellular Endocrinology 2003206 49-62. (https://doi.org/10.1016/ S0303-7207(03)00236-3)

24 Colao A \& Savastano S. Medical treatment of prolactinomas. Nature Reviews Endocrinology 20117 267-278. (https://doi.org/10.1038/ nrendo.2011.37)

25 Colao A, Di Somma C, Pivonello R, Faggiano A, Lombardi G \& Savastano S. Medical therapy for clinically non-functioning pituitary adenomas. Endocrine-Related Cancer 200815 905-915. (https://doi. org/10.1677/ERC-08-0181)

26 Petrossians P, Thonnard AS \& Beckers A. Medical treatment in Cushing's syndrome: dopamine agonists and cabergoline. Neuroendocrinology 201092 116-119. (https://doi. org/10.1159/000317716)

27 Sandret L, Maison P \& Chanson P. Place of cabergoline in acromegaly: a meta-analysis. Journal of Clinical Endocrinology and Metabolism 2011 96 1327-1335. (https://doi.org/10.1210/jc.2010-2443)

28 Park C, Yang I, Woo J, Kim S, Kim J, Kim Y, Sohn S, Kim E, Lee M, Park $\mathrm{H}$ et al. Somatostatin (SRIF) receptor subtype 2 and 5 gene expression in Growth Hormone-secreting pituitary adenomas: the relationship with endogenous srif activity and response to octreotide. Endocrine Journal 200451 227-236. (https://doi.org/10.1507/ endocrj.51.227)

29 Taboada GF, Luque RM, Neto LV, Machado EdO, Sbaffi BC, Domingues RC, Marcondes JB, Chimelli LMC, Fontes R, Niemeyer P et al. Quantitative analysis of somatostatin receptor subtypes (1-5) gene expression levels in somatotropinomas and correlation to in vivo hormonal and tumor volume responses to treatment with octreotide LAR. European Journal of Endocrinology 2008 295-303. (https://doi.org/10.1530/EJE-07-0562)

30 Durán-Prado M, Saveanu A, Luque RM, Gahete MD, GraciaNavarro F, Jaquet P, Dufour H, Malagón MM, Culler MD, Barlier A et al. A potential inhibitory role for the new truncated variant of somatostatin receptor 5, sst5TMD4, in pituitary adenomas poorly responsive to somatostatin analogs. Journal of Clinical Endocrinology and Metabolism 201095 2497-2502. (https://doi.org/10.1210/ jc.2009-2247)

31 Plöckinger U, Reichel M, Fett U, Saeger W \& Quabbe HJü. Preoperative octreotide treatment of Growth Hormone-secreting and clinically nonfunctioning pituitary macroadenomas: effect on tumor volume and lack of correlation with immunohistochemistry and somatostatin receptor scintigraphy. Journal of Clinical Endocrinology and Metabolism 199479 1416-1423. (https://doi.org/10.1210/ jcem.79.5.7962337)

32 Nakashima M, Takano K \& Matsuno A. Analyses of factors influencing the acute effect of octreotide in Growth Hormonesecreting adenomas. Endocrine Journal 200956 295-304. (https://doi. org/10.1507/endocrj.K08E-305)

33 Plöckinger U, Albrecht S, Mawrin C, Saeger W, Buchfelder M, Petersenn S \& Schulz S. Selective loss of somatostatin receptor 2 in octreotide-resistant Growth Hormone-secreting adenomas. Journal of Clinical Endocrinology and Metabolism 200893 1203-1210. (https:// doi.org/10.1210/jc.2007-1986)

34 Plökinger U, Bäder M, Hopfenmüller W, Saeger W \& Quabbe HJ. Results of somatostatin receptor scintigraphy do not predict pituitary tumor volume- and hormone-response to octreotide therapy and do not correlate with tumor histology. European Journal of Endocrinology 1997136 369-376. (https://doi.org/10.1530/eje.0.1360369)
35 Duet M, Ajzenberg C, Benelhadj S, Lajeunie E, Lormeau B, Guillausseau PJ, Rohmer V, Vilain D, Mundler O \& Warnet A. Somatostatin receptor scintigraphy in pituitary adenomas: a somatostatin receptor density index can predict hormonal and tumoral efficacy of octreotide in vivo. Journal of Nuclear Medicine 199940 1252-1256.

36 Casarini APM, Pinto EM, Jallad RS, Giorgi RR, Giannella-Neto D \& Bronstein MD. Dissociation between tumor shrinkage and hormonal response during somatostatin analog treatment in an acromegalic patient: preferential expression of somatostatin receptor subtype 3 . Journal of Endocrinological Investigation 200629 826-830. (https://doi. org/10.1007/BF03347378)

37 Colao A, Auriemma RS, Lombardi G \& Pivonello R. Resistance to somatostatin analogs in acromegaly. Endocrine Reviews 201132 247-271. (https://doi.org/10.1210/er.2010-0002)

38 Legovini P, Menis E De, Billeci D, Conti B, Zoli P \& Conte N. 111Indium-pentetreotide pituitary scintigraphy and hormonal responses to octreotide in acromegalic patients. Journal of Endocrinological Investigation 199720 423-427. (https://doi. org/10.1007/BF03347995)

39 Barlier A, Pellegrini-Bouiller I, Gunz G, Zamora AJ, Jaquet P \& Enjalbert A. Impact of $g s p$ oncogene on the expression of genes coding for $\mathrm{G}_{\mathrm{s}} \alpha$, Pit-1, $\mathrm{G}_{\mathrm{i}} 2 \alpha$, and somatostatin receptor 2 in human somatotroph adenomas: involvement in octreotide sensitivity. Journal of Clinical Endocrinology and Metabolism 199984 2759-2765. (https://doi.org/10.1210/jcem.84.8.5919)

40 Florio T, Thellung S, Arena S, Corsaro A, Spaziante R, Gussoni G, Acuto G, Giusti M, Giordano G \& Schettini G. Somatostatin and its analog lanreotide inhibit the proliferation of dispersed human non-functioning pituitary adenoma cells in vitro. European Journal of Endocrinology 1999141 396-408. (https://doi.org/10.1530/ eje.0.1410396)

41 Hofland LJ, Van Der Hoek J, Van Koetsveld PM, De Herder WW, Waaijers M, Sprij-Mooij D, Bruns C, Weckbecker G, Feelders R, Van Der Lely AJ et al. The novel somatostatin analog SOM230 is a potent inhibitor of hormone release by Growth Hormone- and prolactinsecreting pituitary adenomas in vitro. Journal of Clinical Endocrinology and Metabolism 200489 1577-1585. (https://doi.org/10.1210/ jc.2003-031344)

42 Takei M, Suzuki M, Kajiya H, Ishii Y, Tahara S, Miyakoshi T, Egashira N, Takekoshi S, Sanno N, Teramoto A et al. Immunohistochemical detection of somatostatin receptor (sstr) subtypes $2 \mathrm{~A}$ and 5 in pituitary adenoma from acromegalic patients: good correlation with preoperative response to octreotide. Endocrine Pathology 200718 208-216. (https://doi.org/10.1007/s12022-0079004-0)

43 Ferone D, De Herder WW, Pivonello R, Kros JM, Van Koetsveld PM, De Jong T, Minuto F, Colao A, Lamberts SWJ \& Hofland LJ. Correlation of in vitro and in vivo somatotropic adenoma responsiveness to somatostatin analogs and dopamine agonists with immunohistochemical evaluation of somatostatin and dopamine receptors and electron microscopy. Journal of Clinical Endocrinology and Metabolism 200893 1412-1417. (https://doi.org/10.1210/ jc.2007-1358)

44 Wildemberg LEA, Neto LV, Costa DF, Nasciuti LE, Takiya CM, Alves LM, Rebora A, Minuto F, Ferone D \& Gadelha MR. Low somatostatin receptor subtype 2 , but not dopamine receptor subtype 2 expression predicts the lack of biochemical response of somatotropinomas to treatment with somatostatin analogs. Journal of Endocrinological Investigation 201336 38-43. (https://doi. org/10.3275/8305)

45 Gatto F, Feelders RA, Van Der Pas R, Kros JM, Waaijers M, Sprij-Mooij D, Neggers SJCMM, Van Der Lelij AJ, Minuto F, De Lamberts SWJ et al. Immunoreactivity score using an anti-sst2A receptor monoclonal antibody strongly predicts the biochemical response to adjuvant treatment with somatostatin analogs in 
acromegaly. Journal of Clinical Endocrinology and Metabolism 201398 E66-E71. (https://doi.org/10.1210/jc.2012-2609)

46 Brzana J, Yedinak CG, Gultekin SH, Delashaw JB \& Fleseriu M. Growth Hormone granulation pattern and somatostatin receptor subtype $2 \mathrm{~A}$ correlate with postoperative somatostatin receptor ligand response in acromegaly: a large single center experience. Pituitary 201316 490-498. (https://doi.org/10.1007/s11102-012-0445-1)

47 Marina D, Burman P, Klose M, Casar-Borota O, Luque RM, Castaño JP \& Feldt-Rasmussen U. Truncated somatostatin receptor 5 may modulate therapy response to somatostatin analogues observations in two patients with acromegaly and severe headache. Growth Hormone and IGF Research 201525 262-267. (https://doi. org/10.1016/j.ghir.2015.07.003)

48 Gatto F, Feelders RA, Franck SE, Van Koetsveld PM, Dogan F, Kros JM, Neggers SJCMM, Van Der Lely AJ, Lamberts SWJ, Ferone D et al. In vitro head-to-head comparison between octreotide and pasireotide in GH-secreting pituitary adenomas. Journal of Clinical Endocrinology and Metabolism 2017102 2009-2018. (https://doi.org/10.1210/jc.201700135)

49 Iacovazzo D, Carlsen E, Lugli F, Chiloiro S, Piacentini S, Bianchi A, Giampietro A, Mormando M, Clear AJ, Doglietto F et al. Factors predicting pasireotide responsiveness in somatotroph pituitary adenomas resistant to first-generation somatostatin analogues: an immunohistochemical study. European Journal of Endocrinology 2016 174 241-250. (https://doi.org/10.1530/EJE-15-0832)

50 de Bruin C, Pereira AM, Feelders RA, Romijn JA, Roelfsema F, Sprij-Mooij DM, van Aken MO, van der Lelij AJ, de Herder WW, Lamberts SWJ et al. Coexpression of dopamine and somatostatin receptor subtypes in corticotroph adenomas. Journal of Clinical Endocrinology and Metabolism 200994 1118-1124. (https://doi. org/10.1210/jc.2008-2101)

51 van der Hoek J, Waaijers M, van Koetsveld PM, Sprij-Mooij D, Feelders RA, Schmid HA, Schoeffter P, Hoyer D, Cervia D, Taylor JE et al. Distinct functional properties of native somatostatin receptor subtype 5 compared with subtype 2 in the regulation of ACTH release by corticotroph tumor cells. American Journal of Physiology: Endocrinology and Metabolism 2005289 E278-E287. (https://doi. org/10.1152/ajpendo.00004.2005)

52 Boscaro M, Ludlam WH, Atkinson B, Glusman JE, Petersenn S, Reincke M, Snyder P, Tabarin A, Biller BMK, Findling J et al. Treatment of pituitary-dependent Cushing's disease with the multireceptor ligand somatostatin analog pasireotide (SOM230): a multicenter, Phase II trial. Journal of Clinical Endocrinology and Metabolism 200994 115-122. (https://doi.org/10.1210/jc.2008-1008)

53 Colao A, Petersenn S, Newell-Price J, Findling JW, Gu F, Maldonado M, Schoenherr U, Mills D, Salgado LR, Biller BMK et al. A 12-month Phase 3 study of pasireotide in Cushing's disease. New England Journal of Medicine 2012366 914-924. (https://doi. org/10.1056/NEJMoa1105743)

54 Trementino L, Cardinaletti M, Concettoni C, Marcelli G, Boscaro M \& Arnaldi G. Up-to 5-year efficacy of pasireotide in a patient with Cushing's disease and pre-existing diabetes: literature review and clinical practice considerations. Pituitary 201518 359-365. (https:// doi.org/10.1007/s11102-014-0582-9)

55 Zatelli MC, Piccin D, Tagliati F, Ambrosio MR, Margutti A, Padovani R, Scanarini M, Culler MD \& degli Uberti EC. Somatostatin receptor Subtype 1 selective activation in human growth hormone (GH)- and prolactin (PRL)-secreting pituitary adenomas: effects on cell viability, GH, and PRL secretion. Journal of Clinical Endocrinology and Metabolism 200388 2797-2802. (https://doi.org/10.1210/ jc.2002-021825)

56 Zatelli MC, Piccin D, Bottoni A, Ambrosio MR, Margutti A, Padovani R, Scanarini M, Taylor JE, Culler MD, Cavazzini L et al. Evidence for differential effects of selective somatostatin receptor subtype agonists on beta-subunit and chromogranin A secretion and on cell viability in human nonfunctioning pituitary adenomas in vitro. Journal of Clinical Endocrinology and Metabolism 200489 5181-5188. (https://doi.org/10.1210/jc.2003-031954)

57 Lee M, Lupp A, Mendoza N, Martin N, Beschorner R, Honegger J, Schlegel J, Shively T, Pulz E, Schulz S et al. SSTR3 is a putative target for the medical treatment of gonadotroph adenomas of the pituitary. Endocrine-Related Cancer 201522 111-119. (https://doi.org/10.1530/ ERC-14-0472)

58 Neto LV, Machado EDO, Luque RM, Taboada GF, Marcondes JB, Chimelli LMC, Quintella LP, Niemeyer P, De Carvalho DP, Kineman RD et al. Expression analysis of dopamine receptor subtypes in normal human pituitaries, nonfunctioning pituitary adenomas and somatotropinomas, and the association between dopamine and somatostatin receptors with clinical response to octreotide-LAR in acromegaly. Journal of Clinical Endocrinology and Metabolism 200994 1931-1937. (https://doi.org/10.1210/jc.2008-1826)

59 Vieira Neto L, Wildemberg LE, Moraes AB, Colli LM, Kasuki L, Marques NV, Gasparetto EL, De Castro M, Takiya CM \& Gadelha MR. Dopamine receptor subtype 2 expression profile in nonfunctioning pituitary adenomas and in vivo response to cabergoline therapy. Clinical Endocrinology 201582 739-746. (https://doi.org/10.1111/ cen.12684)

60 Saveanu A, Jaquet P, Brue T \& Barlier A. Relevance of coexpression of somatostatin and dopamine D2 receptors in pituitary adenomas. Molecular and Cellular Endocrinology 2008286 206-213. (https://doi. org/10.1016/j.mce.2007.12.008)

61 Melmed S, Casanueva FF, Hoffman AR, Kleinberg DL, Montori VM, Schlechte JA, Wass JAH \& Endocrine Society. Diagnosis and treatment of hyperprolactinemia: an Endocrine Society Clinical Practice Guideline. Journal of Clinical Endocrinology and Metabolism 201196 273-288. (https://doi.org/10.1210/jc.2010-1692)

62 Raverot G, Burman P, McCormack A, Heaney A, Petersenn S, Popovic V, Trouillas J, Dekkers OM \& European Society of Endocrinology. European Society of Endocrinology Clinical Practice guidelines for the management of aggressive pituitary tumours and carcinomas. European Journal of Endocrinology 2018178 G1-G24. (https://doi.org/10.1530/EJE-17-0796)

63 Oh MC \& Aghi MK. Dopamine agonist-resistant prolactinomas. Journal of Neurological Surgery 2011114 1369-1379. (https://doi. org/10.3171/2010.11.JNS101369)

64 Ono M, Miki N, Kawamata T, Makino R, Amano K, Seki T, Kubo O, Hori T \& Takano K. Prospective study of high-dose cabergoline treatment of prolactinomas in 150 patients. Journal of Clinical Endocrinology and Metabolism 200893 4721-4727. (https://doi. org/10.1210/jc.2007-2758)

65 Delgrange E, Daems T, Verhelst J, Abs R \& Maiter D. Characterization of resistance to the prolactin-lowering effects of cabergoline in macroprolactinomas: a study in 122 patients. European Journal of Endocrinology 2009160 747-752. (https://doi.org/10.1530/EJE-090012)

66 Delgrange E, Raverot G, Bex M, Burman P, Decoudier B, Devuyst F, Feldt-Rasmussen U, Andersen M \& Maiter D. Giant prolactinomas in women. European Journal of Endocrinology 2014170 31-38. (https:// doi.org/10.1530/EJE-13-0503)

67 Khare S, Lila AR, Patt H, Yerawar C, Goroshi M, Bandgar T \& Shah NS. Gender differences in macroprolactinomas: a single centre experience. Endocrine Connections 20165 20-27. (https://doi. org/10.1530/EC-15-0105)

68 Fainstein Day P, Glerean M, Lovazzano S, Pietrani M, Christiansen S, Balzaretti M, Kozak A \& Carrizo A. Gender differences in macroprolactinomas: study of clinical features, outcome of patients and Ki-67 expression in tumor tissue. In Frontiers of Hormone Research, pp 50-58. Eds E Arzt, M Bronstein \& M Guitelman. Basel: KARGER, 2010. (https://doi.org/10.1159/000318494)

69 Caccavelli L, Feron F, Morange I, Rouer E, Benarous R, Dewailly D, Jaquet P, Kordon C \& Enjalbert A. Decreased expression of the two D2 dopamine receptor isoforms in bromocriptine-resistant 
prolactinomas. Neuroendocrinology $199460314-322$. (https://doi. org/10.1159/000126764)

70 Filopanti M, Barbieri AM, Angioni AR, Colao A, Gasco V, Grottoli S, Peri A, Baglioni S, Fustini MF, Pigliaru F et al. Dopamine D2 receptor gene polymorphisms and response to cabergoline therapy in patients with prolactin-secreting pituitary adenomas. Pharmacogenomics Journal 20088 357-363. (https://doi.org/10.1038/tpj.2008.1)

71 Fusco A, Gunz G, Jaquet P, Dufour H, Germanetti AL, Guller MD, Barlier A \& Saveanu A. Somatostatinergic ligands in dopaminesensitive and -resistant prolactinomas. European Journal of Endocrinology 2008158 595-603. (https://doi.org/10.1530/EJE-07-0806)

72 Reubi JC, Schaer JC, Waser B \& Mengod G. Expression and localization of somatostatin receptor SSTR1, SSTR2, and SSTR3 messenger RNAs in primary human tumors using in situ hybridization. Cancer Research $1994 \mathbf{5 4}$ 3455-3459.

73 Nielsen S, Mellemkjaer S, Rasmussen LM, Ledet T, Olsen N, Bojsen-Moller M, Astrup J, Weeke J \& Jorgensen JO. Expression of somatostatin receptors on human pituitary adenomas in vivo and ex vivo. Journal of Endocrinological Investigation 200124 430-437. (https://doi.org/10.1007/BF03351043)

74 Corbetta S, Ballaré E, Mantovani G, Lania A, Losa M, Di Blasio AM $\&$ Spada A. Somatostatin receptor subtype 2 and 5 in human GH-secreting pituitary adenomas: analysis of gene sequence and mRNA expression. European Journal of Clinical Investigation 200131 208-214. (https://doi.org/10.1046/j.1365-2362.2001.00786.x)

75 Gonzalez B, Vargas G, Ramirez C, Asa S, Cheng S, Sandoval C $\&$ Mercado M. Cytoplasmic expression of SSTR 2 and 5 by immunohistochemistry and by RT/PCR is not associated with the pharmacological response to octreotide. Endocrinologia y Nutricion 201461 523-530. (https://doi.org/10.1016/j.endonu.2014.05.006)

76 Ibáñez-Costa A, Rivero-Cortés E, Vázquez-Borrego MC, Gahete MD, Jiménez-Reina L, Venegas-Moreno E, de la Riva A, Arráez MÁ, González-Molero I, Schmid HA et al. Octreotide and pasireotide (dis) similarly inhibit pituitary tumor cells in vitro. Journal of Endocrinology 2016231 135-145. (https://doi.org/10.1530/JOE-16-0332)

77 Casar-Borota O, Heck A, Schulz S, Nesland JM, Ramm-Pettersen J, Lekva T, Alafuzoff I \& Bollerslev J. Expression of SSTR2a, but not of SSTRs 1, 3, or 5 in somatotroph adenomas assessed by monoclonal antibodies was reduced by octreotide and correlated with the acute and long-term effects of octreotide. Journal of Clinical Endocrinology and Metabolism 201398 E1730-E1739. (https://doi.org/10.1210/ jc.2013-2145)

78 Liu W, Xie L, He M, Shen M, Zhu J, Yang Y, Wang M, Hu J, Ye H, Li Y et al. Expression of somatostatin receptor 2 in Somatotropinoma correlated with the short-term efficacy of somatostatin analogues. International Journal of Endocrinology 20172017 9606985. (https:// doi.org/10.1155/2017/9606985)

79 Casarini APM, Jallad RS, Pinto EM, Soares IC, Nonogaki S, GiannellaNeto D, Musolino NR, Alves VAF \& Bronstein MD. Acromegaly: correlation between expression of somatostatin receptor subtypes and response to octreotide-lar treatment. Pituitary 200912 297-303. (https://doi.org/10.1007/s11102-009-0175-1)

80 Fougner SL, Borota OC, Berg JP, Hald JK, Ramm-Pettersen J \& Bollerslev J. The clinical response to somatostatin analogues in acromegaly correlates to the somatostatin receptor subtype $2 \mathrm{a}$ protein expression of the adenoma. Clinical Endocrinology 200868 458-465. (https://doi.org/10.1111/j.1365-2265.2007.03065.x)

81 Gadelha MR, Kasuki L \& Korbonits M. Novel pathway for somatostatin analogs in patients with acromegaly. Trends in Endocrinology and Metabolism 201324 238-246. (https://doi. org/10.1016/j.tem.2012.11.007)

82 Peverelli E, Giardino E, Vitali E, Treppiedi D, Lania AG \& Mantovani G. Filamin A in somatostatin and dopamine receptor regulation in pituitary and the role of CAMP/PKA dependent phosphorylation. Hormone and Metabolic Research 201446 845-853. (https://doi.org/10.1055/s-0034-1384520)

83 Córdoba-Chacón J, Gahete MD, Durán-Prado M, Luque RM \& Castaño JP. Truncated somatostatin receptors as new players in somatostatin-cortistatin pathophysiology. Annals of the New York Academy of Sciences $2011 \mathbf{1 2 2 0}$ 6-15. (https://doi.org/10.1111/j. 1749-6632.2011.05985.x)

84 Ibáñez-Costa A, López-Sánchez LM, Gahete MD, Rivero-Cortés E, Vázquez-Borrego MC, Gálvez MA, La De Riva A, Venegas-Moreno E, Jiménez-Reina L, Moreno-Carazo A et al. BIM-23A760 influences key functional endpoints in pituitary adenomas and normal pituitaries: molecular mechanisms underlying the differential response in adenomas. Scientific Reports 20177 1-14. (https://doi.org/10.1038/ srep42002)

85 Gatto F, Feelders R, Van Der Pas R, Kros JM, Dogan F, Van Koetsveld PM, Van Der Lelij AJ, Neggers SJCMM, Minuto F, De Herder $\mathrm{W}$ et al. $\beta$-Arrestin 1 and 2 and $\mathrm{G}$ protein-coupled receptor kinase 2 expression in pituitary adenomas: role in the regulation of response to somatostatin analogue treatment in patients with acromegaly. Endocrinology 2013154 4715-4725. (https://doi. org/10.1210/en.2013-1672)

86 Fougner SL, Lekva T, Borota OC, Hald JK, Bollerslev J \& Berg JP. The expression of E-cadherin in somatotroph pituitary adenomas is related to tumor size, invasiveness, and somatostatin analog response. Journal of Clinical Endocrinology and Metabolism 201095 2334-2342. (https://doi.org/10.1210/jc.2009-2197)

87 Shimazu S, Shimatsu A, Yamada S, Inoshita N, Nagamura Y, Usui T $\&$ Tsukada T. Resistance to dopamine agonists in prolactinoma is correlated with reduction of dopamine D2 receptor long isoform mRNA levels. European Journal of Endocrinology 2012166 383-390. (https://doi.org/10.1530/EJE-11-0656)

88 Peverelli E, Mantovani G, Vitali E, Elli FM, Olgiati L, Ferrero S, Laws ER, Della Mina P, Villa A, Beck-Peccoz P et al. Filamin-A is essential for dopamine $\mathrm{d} 2$ receptor expression and signaling in tumorous lactotrophs. Journal of Clinical Endocrinology and Metabolism 201297 967-977. (https://doi.org/10.1210/jc.2011-2902)
Received 29 June 2018

Revised version received 13 August 2018

Accepted 22 August 2018 